\title{
Cost Modeling for ABC Failure of Machines
}

Alena Pešková, Peter Demeč

Faculty of Mechanical Engineering, Technical University of Košice, Letná 9, 042 00, Košice, Slovak Republic, E-mail: alena.peskova@tuke.sk,peter.demec@tuke.sk

In this paper we analyze Weibull generated failures of equipment in discrete production. At first we will classify failures using $\mathrm{ABC}$ analysis. Obtained characteristics of each group of failures can be used to generate time of their occurrence and duration which are essential for assessment of their cost. We use optimization tool Solver from MS Office - Excel to solve problem of maintenance of machines. We optimize strategy of maintenance also according to cost of failures in categories ABC classification. Results of this optimization are tables, graphs, having that it can offer to managers a new unconventional access at the efficiency of investment. We create the proposed approach of solving models on demonstration example.

Keywords: Linear Programming Tasks, Cost of Failures, Weibull Distribution of Failures, Optimization Problems

\section{Acknowledgement}

This paper was supported by Project VEGA n. 1/0124/15 Research and development of advanced methods for virtual prototyping of production machines.

\section{References}

[1] JENČURÁKOVÁ,D., PALENČÁR, R. (2016). Optimizing Management of the Measurement System of the Technological Process. In: Manufacturing Technology. Volume 16 pp. 107-113, M201622, ISSN 1213-2489

[2] VASILKO, K., MURČINKOVÁ, Z.(2016). Theoretical and Practical Relationship Rz = f(f;re). In: Manufacturing Technology. Volume 16, pp. 826-830, M2016153, ISSN 1213-2489

[3] MUŠKÁT, P., URBAN, F., BEREZNAI, J., ZÁVODNÝ, Z.(2016). Comparison of Linear and Nonlinear Optimiza tion Methods of Heating Plant Operation. In: Manufacturing Technology. Volume 16 pp. 569-574, M2016109, ISSN 1213-2489

[4] STRAKA, M., KAČMÁRY, P., ROSOVÁ, A., YAKIMOVICH, B., KORSHUNOV, A. (2016). Model of Unique Material Flow in Context with Layout of Manufacturing Facilities. Volume 16 In: Manufacturing Technology. pp. 814-820, M2016151,ISSN 1213-2489

[5] KENNE, J. P., GHARBI, A., BEIT, M. (2007). Age-dependent Production Planning and Maintenance Strategies in Unreliable Manufacturing Systems with Lost sale. In: European Journal of Operational Researc 178 pp.408420

[6] CASSADY, R., KUTANOGLU, E. (2005). Integrating Preventive Maintenance Planning and Production Scheduling for a Single Machine. In: IIEE Transactions, vol. 54, no. 2, pp. 304-309

[7] CALDEIRA, D. J., GUEDES, S. C. (2007). Optimisation of the Preventive Maintenance Plan of a Series Components System with Weibull Hazard Function. In: RTA 3-4, December - Special Issue

[8] ATTIA, A., ELELA, E., HOSMAN, H. (2011). The Optimal Warranty and Preventive Maintenance Policy for the Four-State System. In: International Scholarly Research Network ISRN Applied Mathematics Volume 2011, Arti cle ID 407457, 12 pages doi:10.5402/2011/407457

[9] AHMAD, R., KAMARUDDIN, S. (2011). Maintenance Decisions Making Method for Repairable System by Using Output-based Maintenance Technique. A Case Study at Pulp Manufacturing Industry 978-1-61284-486-2/ 2011 IEEE

[10] TAMBE, P., MOHITE, S., KULKARNI, M. (2013). Optimization of Opportunistic Maintenance of a Multi-component System Considering the Effect of Failures on Quality and Production Schedule. A Case Study. In: Journal of advanced manufacturing Technology DOI 10.1007/s00170-013-5122-7

[11] NAKAWA, T. (2011). Stochastic Processes, 251p. Springer New York. ISBN 978-1-4471-2661-4 